\title{
Does collective bargaining influence the way the size of the firm impacts wage dispersion? Spanish evidence
}

\author{
Juan Francisco Canal Domínguez and César Rodríguez Gutiérrez \\ Department of Economics, Faculty of Economics and Business, University of Oviedo, \\ Oviedo-Asturias, Spain
}

Received 25 June 2018 Revised 7 February 2019 10 October 2019 Accepted 4 December 2019

\begin{abstract}
Purpose - This paper analyses the relationship between wage dispersion and firm size within a "two-tier" system of collective bargaining (firm bargaining and multi-employer bargaining levels). Collective bargaining has a decisive role in setting wages in Spain, and its regulation highly limits the possibility for smaller firms to negotiate their own collective agreement.

Design/methodology/approach - Based on the Spanish Structure of Earnings Survey 2006, 2010 and 2014, the authors use variance decomposition in order to deeply analyse the effect of bargaining level on wage dispersion and compare the value of each decile of the distribution of wages for the purposes of identifying the quantitative differences in wage compression.

Findings - In general, the outcomes positively linked firm size and firm bargaining to wage dispersion. However, if firm size is taken into account, the effect of firm bargaining is limited among small firm workers because this type of firm is not usually covered by firm bargaining. On the other hand, the time analysis allows observing a wage compression that follows different patterns depending on firm size, compressing the higher part of the distribution in case of small firms and the lower part in case of large firms. This should be explained by the fact that wage negotiation is dependent on firm size.

Social implications - Firm size has determined firm adjustment strategies to face the recent economic crisis and allows to evaluate the impact that changes in collective bargaining can have on wage distribution

Originality/value - There is no research that has tried to analyse the relationship between wage dispersion and firm size in a context where collective bargaining is essential to understand the wage structure. Normally, firm size plays a decisive role in wage policy given that the capacity of a company to negotiate an agreement is closely linked to its size.
\end{abstract}

Keywords Wage dispersion, Trade unions, Collective bargaining, Firm size

Paper type Research paper

\section{Introduction}

Recent research warns of an increasing inequality in household income distribution in developed countries since the beginning of the economic crisis (OECD, 2014) and particularly in the Spanish case (see for example, Arranz and Serrano, 2014; Spanish Economic and Social Council, 2014). Canal and Rodríguez (2016) examine how the "two-tier" collective bargaining system affects wage dispersion in Spain within a time framework covering the economic growth (2002-2006) and part of the financial crisis (2006-2010). Contrary to preceding research for the Spanish case, the authors find the existence of wage dispersion reduction at both bargaining levels (firm level and multi-employer level) and during both analysed sub-periods (2002-2006 and 2006-2010).

This research is aimed at deepening our understanding of wage dispersion, paying special attention to firm size, one of the factors that most affect collective bargaining in Spain. Labour economics has widely analysed the relationship between firm size and wages (see, e.g. Brown and Medoff, 1989; Idson and Oi, 1999; Barth and Dale-Olsen, 2011; Pehkonen et al, 2017; Kim

This paper has been funded by the Ministry of Science and Innovation (Project number ECO2017-86402C2-1-R), and by the University of Oviedo (Project number PAPI-19-GR-2014-0076). 
and Konings, 2018). The conclusion reached is the existence of a positive effect of firm size on workers' wages. Much less is known on the relationship between firm size and wage dispersion, despite the influence of wage dispersion on firm performance (according to the efficiency wage theory, wage distribution influences workers' incentives), labour force allocation (wage differences are key to identify differences in terms of productivity and, therefore, to efficiently allocate the labour force) and from social equality's point of view (wage dispersion affects differences in household income, whose main component is wages)[1].

In research papers by Davis and Haltiwanger (1996), and Lallemand and Rycx (2005), we can find a summary of the main explanatory hypotheses about how firm size can affect wage dispersion. First of all, in relation to within-firm wage dispersion, there are "for and against" grounds, as large firms present higher wage dispersion than the small ones. Among the "for" grounds:

(1) Large firms employ workers with greater skill heterogeneity.

(2) Implement incentive-based pay schemes more heavily.

(3) Tournament theories suggest that employers should implement some wage dispersion in order to foster average worker's effort: the higher the number of contestants for a prize, the larger the wage differential to enhance worker's productivity.

On the other hand, some "against" grounds are:

(1) Large firms are more likely to use technologies that require homogeneous workers.

(2) Use standard pay rate policies that link wages to easily observable worker characteristics to reduce their high monitoring costs.

(3) Targets of union (which have a greater presence in large companies) drives are oriented to compress wages among workers.

Secondly, as far as between-firm wage dispersion is concerned, it is believed that the smaller the firm size, the greater the wage dispersion, because small firms use a wide range of production technologies and unions are more prevalent among larger firms, which compress wages across occupations.

Therefore, from a theoretical point of view, the existence of either a positive or a negative relation between firm size and wage dispersion cannot be confirmed. The study of Davis and Haltiwanger (1996) on the US manufacturing sector in 1982 shows that within-firm wage dispersion increases, in general, with firm size, due to a greater heterogeneity in workers' skills at large firms. The study of Lallemand and Rycx (2005) examines firms in four European countries (i.e. Belgium, Ireland, Italy and Spain), and the findings are very similar to those of Davis and Haltiwanger (1996) for the United States.

Terviö (2008), and Gabaix and Landier (2008) consider that wage policies that pay out high wages to CEOs have been questioned to contribute to growing earnings. More talented CEOs are matched with larger firms, resulting in a positive relationship between firm size and CEO pay inequality. However, Mueller et al. (2017a, b) consider that, although CEO pay rise over the past decades has been remarkable, it can hardly explain the rise in aggregate wage inequality. Hence, if more talented managers are matched with larger firms, we should expect to see a positive relationship between firm size and both CEO pay and the pay of other managers along the firm hierarchy. Using firm-level survey data on employee pay in the United Kingdom between 2004 and 2013, their results show that larger firms show significantly more pay inequality: wage differentials between top-level and bottom-level jobs and also between different top-level jobs all increase with firm size. By contrast, wage differentials among several lower hierarchy levels do not vary depending on firm size. On the 
other hand, Kim and Konings (2018) analyse how firm size and exposure to international trade may have contributed to wage dispersion within firms. Using a data set of Korean firms for the 2007-2013 period, they find that within-firm wage inequality increases with its size, and they also find a positive impact of internationalization on wage inequality.

The within-firm analysis raises the question of whether firm growth can possibly explain the rise in aggregate wage dispersion. Davis and Haltiwanger (1996) find that between-firm wage dispersion decreases with firm size, on the grounds that small firms are technologically more diverse than large firms. On the other hand, Mueller et al. (2017a), using wage data from 15 developed countries, document a positive association between aggregate wage dispersion at country level and the growth of the largest firms in the economy. Kim and Konings (2018) suggest that an important source of the observed wage inequality can be explained by the observed heterogeneity between firms in terms of size and international orientation. Given that the highly skewed size distribution is observed in most economies, size seems to be important to explain the rise in wage inequality and polarization.

Nevertheless, it must be highlighted that none the earlier referred papers have deeply analysed potential collective bargaining influence on the relationship between firm size and wage dispersion, which turns out to be surprising given the relevance of the collective bargaining in wage setting (Calmfors and Driffill, 1988). The effects of different collective bargaining models on wage levels and wage dispersion are significant for an understanding of the different ways in which firms adjust wages to market conditions. Teulings and Hartog (1998), Wallerstein (1999) and Blau and Kahn (1999) conclude that unions reduce wage dispersion and that the effect of this compression is stronger where union membership and bargaining coverage are greater, together with high levels of centralisation and/or co-ordination of collective bargaining. This is due to two factors: within centralised countries, multi-employer agreements set minimum wages that increase wages at the bottom of the wage distribution; in addition, multi-employer bargaining (MB) coordinates wage setting, so inter-industry and inter-firm wage differentials are lower than in less coordinated systems of collective bargaining (Canal and Rodríguez, 2016).

This research is aimed at expanding the knowledge on the effect that trade union activity has on wage dispersion, while making an innovative contribution by jointly assessing the effect of firm size and collective bargaining on between-firm wage dispersion. Particularly, the aim of this paper is to assess to what extend collective bargaining structure influences the way the size of the firm impacts wage dispersion. This research turns out to be especially relevant given that the wage setting mechanism stated in the collective bargaining is closely related to firm size (Ashenfelter and Layard, 1986).

For this reason, the Spanish case is proposed, where the analysis of wage setting must take into account the legal framework of worker-firm negotiations. Collective bargaining in Spain establishes certain rules to negotiate both wages and other working conditions, which are decisive when setting wages, given that collective bargaining coverage in the private sector is close to 100 per cent (Canal and Rodríguez, 2004).

The Spanish collective bargaining model is unusual within the European context, where the dominant bargaining level is the provincial sector (NUT3 according to Eurostat terminology), while firm bargaining (FB) level remains minor (García-Serrano and Malo, 2002). Spain is thus at an intermediate level, in terms of both centralisation and collective bargaining coordination (OECD, 2004).

Spain, as Italy and Belgium, has adopted a multi-level system of bargaining (a "two-tier" system), where firm-level bargaining developed alongside MB (Dell'Aringa and Pagani, 2007). According to the Spanish bargaining system, every firm is under a multi-employer (national or regional) bargaining, whereas some firms may decide (as agreed with its workers) to negotiate its own firm collective agreement. In this case, the law states that a firm's bargaining must improve the working conditions agreed on in the MB. However, there are 
certain regulations on labour relations that cannot be negotiated at firm level, because either they are regulated by law or can only be negotiated at the MB level (Canal and Rodríguez, 2004).

A firm's decision to negotiate its own collective agreement is strongly linked to firm size, as the Workers' Statute (Estatuto de los Trabajadores, the law that establishes basic labour relations regulation) establishes that companies with less than six workers cannot negotiate their own collective agreement, and those between six and ten may choose a representative to negotiate their own, so that the FB is quite unlikely. The influence of this rule on collective bargaining and, therefore, on wage setting, is very important, as according to National Statistical Institute (INE), 90 per cent of Spanish firms employed less than 10 workers in 2017 (www.ine.es).

Therefore, collective bargaining determines wage setting and its dispersion. It must be considered that negotiators' strategies and salaries agreed in the negotiation will be determined by the negotiating level: firm or multi-employer level (Canal and Rodríguez, 2016). Given that a firm's ability to negotiate its own collective agreement and, therefore, to negotiate different salaries from those agreed on in its corresponding multi-employer collective bargaining is closely linked to its size. The question we are here trying to answer is: to what extent does collective bargaining structure influence the way the size of the firm impacts wage dispersion? We will use the Spanish Structure of Earnings Survey (SSES) by the INE for 2006, 2010 and 2014, as the source of information in order to answer this question. SSES is the common source used in Spain to have a picture of wage evolution.

The paper is divided as follows. Section 2 summarizes the theoretical base to explain trade unions' activity on wage dispersion according to firm size, as well as the empirical evidence. Section 3 presents the database, whereas Section 4 presents a descriptive data analysis. Section 5 estimates the effect of the collective bargaining on wage dispersion depending on firm size, while Section 6 states if the results may be related to a different wage negotiation strategy based on firm size. Finally, Section 7 presents the most relevant outcomes.

\section{Bargaining and the relationship between firms' size and wage dispersion}

There are different theories about how firm size is likely to influence trade union activity and, therefore, wage setting. In relation to wage level setting, there are many studies that have dealt with the relationship between the size and the collective bargaining together with other factors, such as the different training levels among workers, technology gaps or economies of scale (see Lallemand and Rycx, 2007), for a summary of the literature). However, regarding wage dispersion, there are hardly any studies that relate firm size and union activity. From a theoretical point of view, Davis and Haltiwanger (1996) and Lallemand and Rycx (2005) consider that taken the empirical evidence that proves the existence of trade union policies based on defending standardized remuneration systems, and on reducing the number of job and pay classifications, it may be inferred that trade unions tend to compress wages, so that within and between-firms, wage dispersions are found to be lower within unionised firms. It is also considered that union power or threat is in general stronger within large companies, then we may expect both between and within-firm dispersions of wages to fall with employer size.

Nevertheless, Davis and Haltiwanger (1996), in a paper that used US manufacturing sector data and which studied how the hourly wage structure varies with establishment size, highlighted that they did not find any evidence that union contract coverage played an important role in the relationship between firm size and wage dispersion. Precisely, in relation to production workers, they found little evidence that union contract coverage compresses the residual wage distribution in any size class. In relation to non-production workers, union contract coverage compressed residual wage dispersion, but this effect had small consequences because of low union coverage rates. 
We should consider that Davis and Haltiwanger's (1996) paper was written more than 20 years ago within the North American labour market framework. On the other hand, in continental Europe, the bargaining regime is quite different from the US pattern. Indeed, wage bargaining takes place at different levels: national, sectoral, regional and/or local. Several studies have shown that the collective bargaining level has an impact on wage dispersion within and between firms (Dell'Aringa and Lucifora, 1994; Canal and Rodríguez, 2004; Plasman et al., 2006; Card and de la Rica, 2006; Dell'Aringa and Pagani, 2007). However, there is no consensus about the sign of this effect. Therefore, it is not clear whether large firms, which are expected to renegotiate wages more frequently at the local level, should show higher or lower wage dispersion levels.

As for the Spanish case, there are very few papers analysing the determinants and the evolution of wage dispersion, and none of them analysed firm size impacts on wage dispersion. Using data from the Structure, Biography and Class-Consciousness Survey carried out in 1991, Dolado et al. (1997) found that unions succeeded in reducing wage dispersion, and they concluded that "unions care for skilled and unskilled workers and bargain binding rates for both. However, they care less for the former and aim to achieve larger wage gains for the latter" (p. 720). Rodríguez (2001) studied wage dispersion determinants at firm level, using a sample of firms that had negotiated their own collective agreements during the period 1990-1994. He concluded that, ceteris paribus, wage dispersion decreases significantly as union density rises. Bover et al. (2002), using a data set of Social Security records, analysed the evolution of earnings inequality in Spain over the 1980s and found that labour union activity tended to reduce inequality across skill groups. On the other hand, Palacio and Simón (2002, 2004), based on SSES 1995, concluded that wage dispersion in Spain was too high by international standards, as workers' wages depended heavily on firm features rather than on their own qualifications. While collective bargaining exercised some wage compression effect, this was too limited. Canal and Rodríguez (2004), using data from SSES 1995, analysed the effect of collective bargaining on within-firm wage dispersion in Spain. The authors found that while firm-level collective agreements tend to reduce wage dispersion, other characteristics of the firms covered by such agreements (such as firm size and workers' average education level) more than outweighed this effect, so that, on the whole, these firms showed greater internal wage dispersion. Plasman et al. (2006) showed that wage dispersion is lower at FB compared to MB in Spain. This result differs from those of Card and de la Rica (2006), which again used the SSES 1995 dataset to show that FB was linked to a more flexible wage determination process. Dell'Aringa and Pagani (2007) found a small positive effect of $\mathrm{FB}$ on wage dispersion for Spain by using a quantile regression model and taking unobserved heterogeneity into account, thus consistent with Card and de la Rica (2006). Finally, Canal and Rodriguez (2016) using data from the SSES for the years 2002, 2006 and 2010, analysed the effect of the Spanish "two-tier" collective bargaining system on wage dispersion. The outcomes indicated that workers covered by FB showed greater wage dispersion. Moreover, wage dispersion was mainly reduced during the first phase of the financial crisis and particularly among workers covered by MB.

\section{The data}

We use data from the Spanish Structure of Earnings Survey (SSES) for the years 2006, 2010 and 2014 provided by the INE. Such survey comprises the whole national territory and covers workers in the manufacturing, construction and services sectors[2]. The SSES collects detailed information on workers' wages, as well as on workers' personal characteristics (such as gender, age, educational attainment and nationality), job characteristics (such as tenure, occupation, contract and job type) and firm characteristics (such as size, ownership, region, sector or type of collective bargaining). 
Hereinafter, in order to make the analysis easier, we simplify the bargaining structure by splitting workers into those covered by FB and those covered by MB (any negotiation level above firm level, mostly national and regional, within its activity sector).

In order to better understand both the data and its later econometric analysis, firms have been classified in two groups according to size: small (less than 50 workers) and large (50 workers and more)[3]. Based on this classification, according to the INE, 98 per cent of Spanish companies were small in 2017 (www.ine.es). According to the OECD latest available data, these firms employed 60 per cent of workers in the private sector in 2015 (www.oecd. $\mathrm{com}$ ). According to these data and collective bargaining rules, a large number of workers from the private sector are not covered by FB.

Variables stated in Table I make it possible to have a picture of workers at small and large firms for every analysed year. As far as personal characteristics are concerned, it can be seen that distribution by gender is more balanced in case of large firms, where we also find older workers. It is also observed that workers at large firms show a higher education level, which leads to a higher percentage of white-collar workers. Besides, their contractual relation tends to be longer, more stable and more likely to be on a full-time basis. In relation to firm features, the manufacturing sector is the predominant, although the financial crisis redistributed workers among other sectors in favour of professional services to companies. As for small firms, the construction sector is becoming increasingly important, whereas trade is the favoured one in case of large firms. Finally, a firm collective bargaining covers a residual percentage of workers at small firms, but around a third at large ones.

\section{Wage dispersion and firm size: a descriptive analysis}

The examined wage concept (expressed logarithmically) is the hourly wage in the October of each analysed year. The survey contains very accurate information on payments made to workers by the firm, so we can identify each worker's minimum wage (contractual wage) and the wage he/she earns (actual wage). The actual wage represents the total labour cost for the company, while the contractual wage is the minimum bargained wage for a normal worker's performance. Therefore, the actual wage is the contractual wage plus any other variable supplement paid by firms in October and the overtime payment (year bonuses paid in October are not included). Wages in 2010 and 2014 have been deflated and expressed in 2006 Euro, based on the 2006 Spanish Consumer Price Index (IPC).

Table II states actual wage variance for sub-samples of workers at small and large firms. It can be observed that actual wage dispersion is higher among workers at large companies. This outcome differs from the ones obtained by Davis and Haltiwanger (1996) and Lallemand and Rycx (2005), according to whom between-wage dispersion decreased as firm size increased, an outcome that they justified according to the hypothesis that small firms were technologically more diverse than the large ones.

On the other hand, in Table II, time analysis allows concluding that wage dispersion was reduced along the financial crisis (both small and large firms), as Canal and Rodríguez (2016) also stated, and to a greater extent, among the group of workers at small firms.

In order to assess whether the collective bargaining could have conditioned these outcomes, it is necessary to know how workers are distributed within both basic bargaining levels: FB and MB. Table III shows that MB is the dominating level; it can also be clearly observed that $\mathrm{FB}$ at small firms is a residual bargaining level, whereas its coverage reached up to 30 per cent at large firms in 2010 and 2014. The different distribution of these negotiation levels depending on firm size is closely related to the aforementioned legal restrictions regarding the decision of a firm to negotiate its own collective agreement.

Taking this collective bargaining distribution into account, Table IV shows actual wage variance for employees at large and small firms, according to the type of collective 


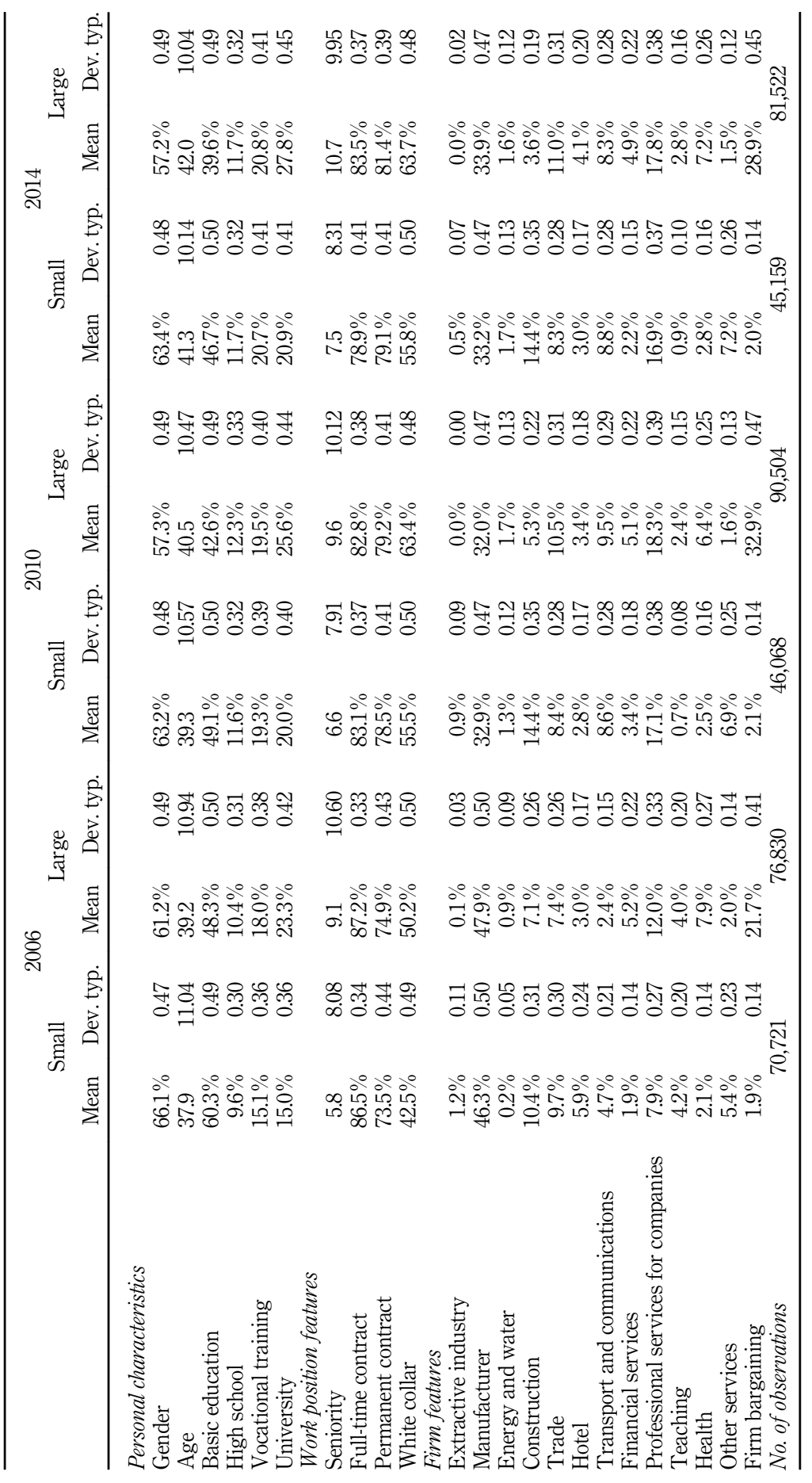


bargaining. It is observed that wage dispersion is higher at FB level. This outcome was obtained by Gerlach and Stephan (2006) and Canal and Rodriguez (2016). However, despite the fact that workers at small firms covered by FB show a higher wage dispersion, the residual coverage of this collective bargaining level proves that small firm workers eventually show a lower wage dispersion, as it is stated in Table II.

The information stated in Table II also allows concluding that wage dispersion reduction is more intense among small firm workers. The information contained in Table IV makes it possible to link this behaviour to the collective bargaining. In case of small firm workers, their wage compression is related to the great effect exercised by $\mathrm{MB}$, as the percentage of workers covered by a FB is residual. In case of large firm workers, wage compression is low because the effect of $\mathrm{MB}$ is more reduced than in the case of small firms and also because the effect of the FB that now covers one-third of workers is almost null.

Therefore, the descriptive analysis seems to point out that collective bargaining affects different wage dispersions depending on firm size. In order to deeply analyse bargaining level impacts on wage dispersion, the variance decomposition given by Dell'Aringa and Pagani (2007) is performed in the following section.

\section{Assessment of the effect of collective bargaining on wage dispersion}

The analysis begins by splitting the sample into workers from small and large firms. Then, two standard log wage equations are estimated, one for the sub-sample of workers covered by $\mathrm{FB}$ and the other for the sub-sample of workers covered by MB.

Table II.

Actual wage logarithm: variance according to firm size

\begin{tabular}{lccc}
\hline & 2006 & 2010 & 2014 \\
\hline Small firm & 0.219 & 0.178 & 0.170 \\
Large firm & 0.289 & 0.255 & 0.246 \\
\hline
\end{tabular}

\begin{tabular}{lrrr}
\hline & 2006 & 2010 & 2014 \\
\hline Small firm & & & \\
Firm bargaining & $1.9 \%$ & $2.1 \%$ & $2.0 \%$ \\
Multi-employer bargaining & $98.1 \%$ & $97.9 \%$ & $98.0 \%$ \\
Large firm & & & \\
Firm bargaining & $21.7 \%$ & $32.9 \%$ & $28.9 \%$ \\
Multi-employer bargaining & $78.3 \%$ & $67.1 \%$ & $71.1 \%$ \\
All workers & & & \\
Firm bargaining & $12.2 \%$ & $20.9 \%$ & $17.8 \%$ \\
Multi-employer bargaining & $87.8 \%$ & $79.1 \%$ & $82.2 \%$ \\
\hline
\end{tabular}

Table III.

Distribution of workers according to bargaining level and firm size. SSES

\begin{tabular}{lccr}
\hline & 2006 & 2010 & 2014 \\
\hline Small firm & & & \\
Firm bargaining & 0.315 & 0.259 & 0.283 \\
Multi-employer bargaining & 0.216 & 0.174 & 0.167 \\
Large firm & & & \\
Firm bargaining & 0.249 & 0.261 & 0.245 \\
Multi-employer bargaining & 0.243 & 0.240 & 0.234 \\
\hline
\end{tabular}




$$
\begin{gathered}
\log w_{\mathrm{FB}}=X_{\mathrm{FB}} \beta_{\mathrm{FB}}+\varepsilon_{\mathrm{FB}} \\
\log w_{\mathrm{MB}}=X_{\mathrm{MB}} \beta_{\mathrm{MB}}+\varepsilon_{\mathrm{MB}}
\end{gathered}
$$

where $w$ is the actual wage, $X$ is a vector of workers' and firms' characteristics[4], $\beta$ is a vector of coefficients and $\varepsilon$ is a vector of error terms. For the purposes of dealing with the possible endogeneity of worker's seniority variable at the firm (as Sulis, 2014 points out), we have estimated the equations (1) and (2) via two-stage least squares (2SLS), as the information provided by SSES is not a panel data. Estimates have undergone endogeneity tests, weak instruments tests and over-identification tests[5].

Once estimates are carried out, we proceed to decompose the variance of log wages for each sub-sample of workers depending on firm size, that is, including every worker regardless of the bargaining level they belong to $(\operatorname{Var} X \beta+\varepsilon)$, into three components. The first component represents the part of the variance attributable to wage differences due to differences among worker and firm observable characteristics:

$$
s \times \operatorname{Var}\left(X_{\mathrm{FB}} \beta_{\mathrm{FB}} \mid \mathrm{FB}\right)+(1-s) \times \operatorname{Var}\left(X_{\mathrm{MB}} \beta_{\mathrm{MB}} \mid \mathrm{MB}\right)
$$

where $s$ and $(1-s)$ are the fraction of workers covered by FB and MB.

The second component represents the part of the variance attributable to wage differences due to differences among non-observable characteristics, that is, differences in the variance of the error terms:

$$
s \times \operatorname{Var}\left(\varepsilon_{\mathrm{FB}} \mid \mathrm{FB}\right)+(1-s) \times \operatorname{Var}\left(\varepsilon_{\mathrm{MB}} \mid \mathrm{MB}\right)
$$

Finally, the third component represents the part of the variance due to the wage gap between the two groups of workers:

$$
\bar{X}_{\mathrm{FB}} \beta_{\mathrm{FB}}-\bar{X}_{\mathrm{MB}} \beta_{\mathrm{MB}}
$$

where $\bar{X}_{\mathrm{FB}}$ and $\bar{X}_{\mathrm{MB}}$ are the mean values of the explanatory variables computed on the two samples of $\mathrm{FB}$ and $\mathrm{MB}$ workers.

Table $\mathrm{V}$ shows the decomposition results for both small firms and large firms. In columns 1,4 and 7 , we see that the part of the variance attributable to both observable (lines 2 and 10) and non-observable (lines 5 and 13) characteristics was greater in case of workers covered by FB (except for large firms in 2006 and 2014), following the fact that workers covered by FB present greater wage variance. It can also be observed that in case of workers at small firms, the estimated wage variance (line 8) is lower than that of large firm workers (line 16), according to Table II values, as well as the values of the different components into which this estimated variance was broken (lines 3, 6 and 7).

In order to assess this effect globally, the previous exercise will be repeated for the counterfactual variance, which is the variance to be observed if the characteristics of workers (and their firms) covered by FB were paid as in the sample of workers covered by MB (columns 2, 5 and 8). The difference between the current variance and counterfactual variance may be FB effect on wage variance after controlling for composition effects (columns 3, 6 and 9). Following the method proposed by DiNardo and Lemieux (1997), wage equation coefficients of the sub-sample of workers covered by $\mathrm{MB}$ will be applied to the distribution of both observable and non-observable characteristics of workers covered by FB. As it can be observed in lines 8 and 16 (columns 3, 6 and 9), the effect is positive. This means that FB exercises a positive effect on wage dispersion, in line with the results obtained by Card and De la Rica (2006), Dell'Aringa and Pagani (2007) and Canal and Rodríguez (2016). Besides, the contribution of the three effects (lines 3, 6 and 7 for small firms, and 11, 14 and 15 for large firms) is, in general, positive, which confirms that in the "two-tier" system of collective 
IJM

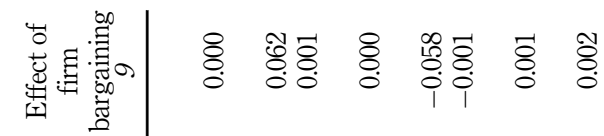

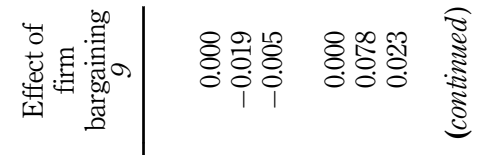

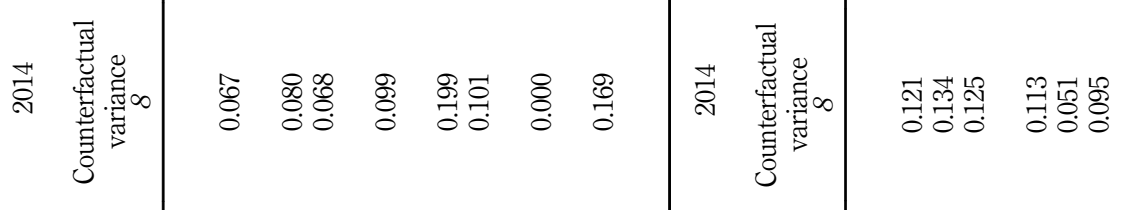

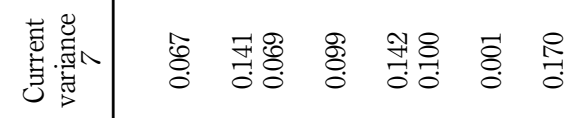

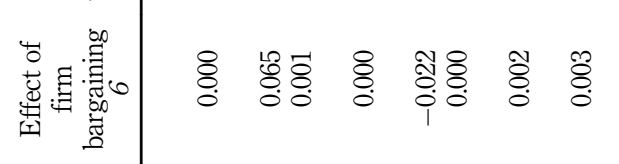

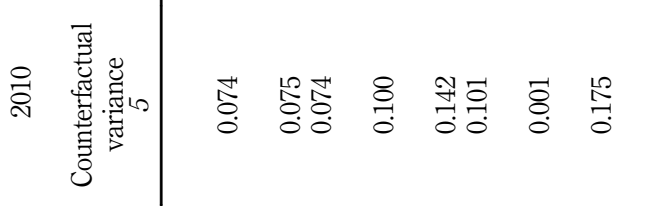

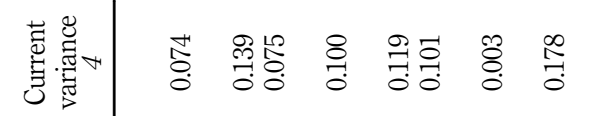

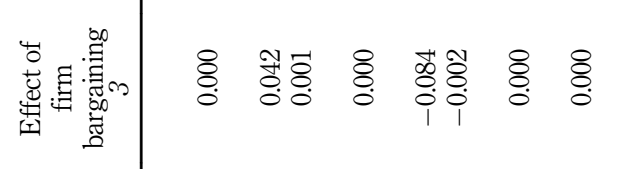

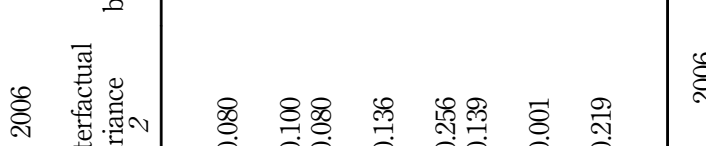

Table V.

Variance

decomposition. Actual wage logarithm 


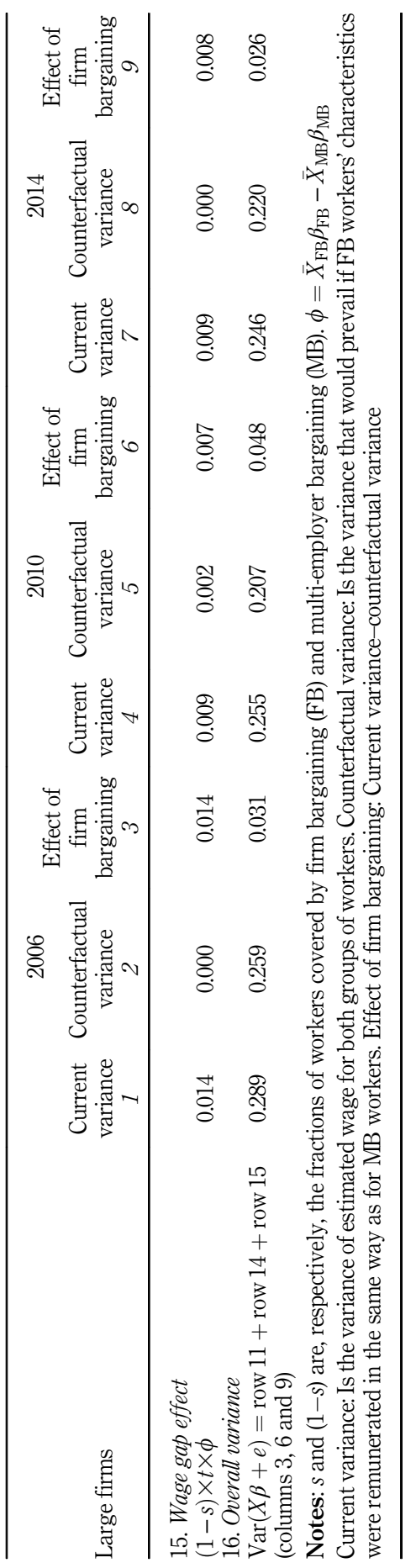

dispersion and firm size 
bargaining, wage dispersion is boosted by FB. Finally, after splitting the sample into large and small firms, we may infer that wage dispersion (line 8 for workers at small firms, and line 16 for workers at large firms) is lower among small firm workers as bargaining effect is lower too, because each component contribution (lines 3, 6 and 7) is weighed by the lack of coverage given by FB.

\section{Do negotiators design different wage policies according to firm size and bargaining level?}

The data provided until now indicate that trade union activity has a significant effect on wage dispersion. Particularly, FB tends to create greater wage dispersion at both small and large firms. However, low wage dispersion among small firm workers is coming from the fact that FB covers a much reduced percentage of workers, which limits the positive effect of FB on wage dispersion.

On the other hand, time analysis allows observing that dispersion was limited for all workers, mainly due to the MB effect. Besides, Table IV data and variance analysis outcomes let us infer that the greater wage compression undergone by small firm workers is closely linked to the fact that, on the one hand, FB within this group of firms is less powerful, and, on the other, that the MB exercises a major compressor effect.

For the purposes of identifying if these quantitative differences in wage compression were negotiated in a different way depending on firm size, we have first proceeded to compare each wage distribution decile value for the years 2014 and 2006, for the sub-sample of workers at small and large firms.

According to Table II data, Figure 1 clearly shows the existence of wage compression for both worker sub-samples, because as we move along the distribution, positive difference values reduce and negative ones increase. We see that the behaviour is different depending on firm size, so we can observe two different patterns in wage compression: compression pushes low wages up in small firms; compression pushes high wages down in large firms. Summing up, wage changes found between 2006 and 2014 favour workers earning less, regardless of firm size. However, wage differentials are always higher in case of smaller firms.

In order to assess whether a collective bargaining could have caused this behavioural pattern, Figures 2 and 3 repeated the analysis for both bargaining levels, but distinguishing firm size.

Figure 1.

Actual wages.

Percentage variation of each decile value between the years 2006 and 2014. A positive value indicates that decile value was higher in 2014

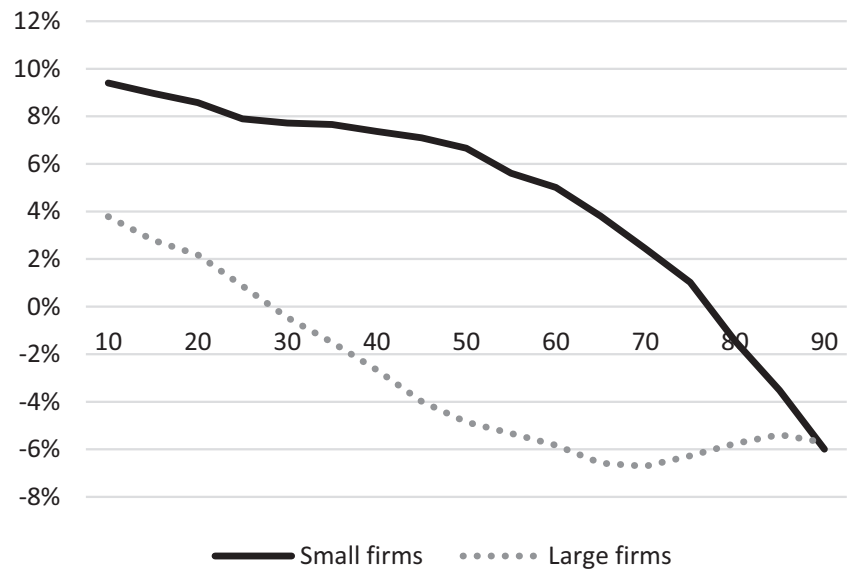


Figure 2 shows the case of workers covered by FB. Workers at small and large firms present quite constant wage dispersion, as it can be inferred from the stability of wage gaps in almost the whole distribution.

In case of workers covered by $\mathrm{MB}$ (Figure 3), the wages of those at small firms undergo compression from the bottom, given the presence of negative values just at the upper part of the distribution. In case of workers at large firms, and compared to their peers at small firms, it is observed that wages are less compressed from the bottom as positive differences are lower in the lowest part of the distribution.

We can draw three conclusions from this analysis. First of all, in line with Canal and Rodríguez's (2016) outcomes, there is wage compression regardless of firm size. Secondly, in case of workers covered by $\mathrm{FB}$, wages have hardly compressed regardless of firm size. Therefore, the wage distribution compression undergone by workers between 2006 and 2014 was due to a wage compression affecting workers covered by MB regardless of the firm size (following Table III, the majority of Spanish workers are covered by MB). Thirdly, the different wage compression behaviours observed among firm sizes can be explained by different wage policies followed by the MB. While policies followed by small firms imply wage distribution compression from the bottom, large firms' wage policies cause wage distribution compression from the top.

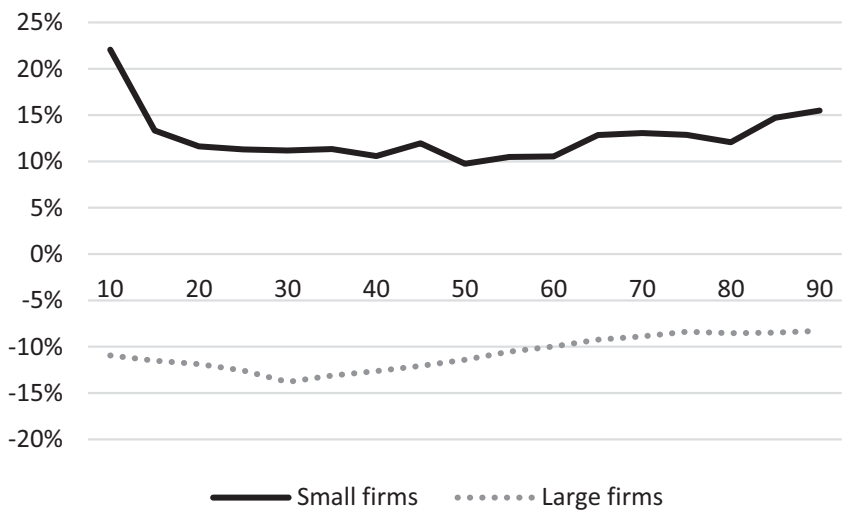

Figure 2. Actual wages. Workers covered by firm bargaining. Percentage variation of each distribution decile value between 2006 and 2014. A positive value indicates that decile value was higher in 2014

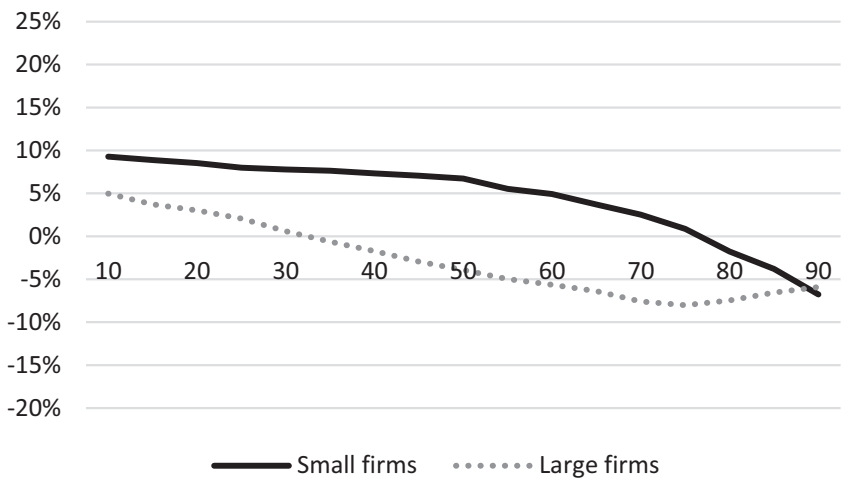

Figure 3. Actual wages. Workers covered by multiemployer bargaining. Percentage variation of each distribution decile value between 2006 and 2014. A positive value indicates that decile value was higher in 2014 
Table VI data make it possible to understand this outcome. We see that, facing the financial crisis, small firms adjusted themselves by mainly laying off employees, whereas large firms did it through a reduction in wages and laying off employees. Large firms covered by MB carried out their wage adjustment through actual wage variable components, which allowed firms to adjust their specific financial situation to the general one defined by the collective bargaining. These variable components were more numerous and frequent at large firms, which paid therefore higher wages, and so, present higher wage dispersion, as wage variable component was more relevant in the upper part of wage distribution (see Canal and Rodríguez, 2016). The reduction or elimination of these components caused wage compression from the upper part of the distribution. The 2012 labour reform favoured this way of firm adjustment by weakening workers' negotiating power, as it made it easier for employers to "withdraw" from the collective agreement, should a series of economic circumstances take place, thus avoiding a Lay-Off Plan (ERE) (Rodríguez and Canal, 2016). Large firms which negotiated their own collective agreement could adapt their wage components to their economic-financial situation, which contributed to a greater wage distribution stability.

On the other hand, small firms mostly regulated by MB chose a way of adjustment through employment. As it can be observed in Table II, these firms employed less qualified and less firm-committed workers, which meant lower wages and low wage dispersion. It was cheaper to fire these workers at these firms, and it did not require any type of negotiation with them as the Spanish negotiation model is right-to-manage type (Lorences et al., 1994). The dismissal of workers from the lower part of the wage distribution made decile value increase in this part of the wage distribution, thus causing an increase of wage average and generating wage compression from the bottom.

\section{Conclusions}

Firm size effect on workers' wage level has been widely analysed by labour economics, while its effect on wage dispersion has not. However, it is even more surprising that papers assessing firm size effects on wage dispersion have not taken collective bargaining into account. Collective bargaining implies guidelines that rule wage setting. If those guidelines are defined according to firm size, to ignore the effect of collective bargaining when

\begin{tabular}{lcccr}
\hline & \multicolumn{2}{c}{ Actual wages } & & \\
& 2006 & 2010 & 2014 & Dif. 06-14 \\
\hline Small firm & 2.163 & 2.240 & 2.210 & $2.2 \%$ \\
Firm bargaining & 2.345 & 2.588 & 2.478 & $5.7 \%$ \\
Multi-employer bargaining & 2.159 & 2.233 & 2.204 & $2.1 \%$ \\
Large firm & 2.462 & 2.471 & 2.439 & $-0.9 \%$ \\
Firm bargaining & 2.686 & 2.606 & 2.585 & $-3.7 \%$ \\
Multi-employer bargaining & 2.400 & 2.405 & 2.380 & $-0.9 \%$ \\
Source: SSES & & & & \\
\hline
\end{tabular}

Table VI.

Actual wage logarithm according to bargaining level and firm size. Number of employees by firm size

\begin{tabular}{lrrrr}
\hline \multicolumn{3}{c}{ Employees } & & \\
& 2006 & 2010 & \multicolumn{1}{c}{2014} & Dif. 06-14 \\
\hline Small firm & $8,701,657$ & $7,332,996$ & $6,289,558$ & $-27.7 \%$ \\
Large firm & $4,902,615$ & $4,497,079$ & $4,164,446$ & $-15.1 \%$ \\
Total & $13,604,272$ & $11,830,075$ & $10,454,004$ & $-23.2 \%$ \\
Source: OECD & & & & \\
\hline
\end{tabular}


explaining wage dispersion can only introduce a significant bias in the outcomes of the empirical analysis.

In the Spanish case, an analysis of the extent the structure of the collective bargaining influences the way the size of the firm impacts wage dispersion is especially significant given that wage setting at the private sector is through collective bargaining, whose regulations establish limits to FB for small firms, which represent 98 per cent of the total number of firms in Spain.

The outcomes indicate that small firm workers present low wage dispersion. This outcome contrasts with Davis and Haltiwanger's (1996) outcomes, but in line with Mueller et al. (2017a) and Kim and Konings (2018).

In the Spanish case, the analysis of wages both in levels and in distribution must take into account the influence of the collective bargaining system, given that collective bargaining coverage in the private sector is close to 100 per cent. In this sense, variance analysis indicates that FB tends to increase wage dispersion, regardless of firm size. However, its effect is less in case of small firm workers, as firm bargaining coverage level is highly reduced for this segment of workers. That is, collective bargaining regulations influence wage dispersion according to firm size by limiting FB at small firms.

Besides, time analysis allows reaching the conclusion that wage dispersion has been reduced during the analysis period, especially in case of small firm workers. This is related to the fact that wage compression is mainly caused by $\mathrm{MB}$ as this rules the labour relations of the majority of workers at small Spanish firms. This time, analysis also allows providing empirical evidence on the existence of different patterns within wage compression regardless of whether we are analysing workers at large or small firms. Therefore, an analysis of wage per decile was carried out for the years between 2006 and 2014. It is particularly observed that in case of small firm workers, compression is at the upper part of the distribution, whereas it is at the bottom at large firms. The explanation is to be found out in the wage policy resulting from the collective bargaining and influenced by firm size, which determined firm adjustment strategy when facing the effects of the financial crisis.

Therefore, this research demonstrates that, in order to understand wage distribution in those countries where collective bargaining regulates labour relations, something common in Europe, it is necessary to analyse the regulations related to collective bargaining key matters and their economic effects. In this particular case, it has been demonstrated how firm size affects wage setting and distribution by limiting the possibilities of negotiation.

It is always harder to negotiate a collective agreement in small firms, as it is easier for the employer to exercise some pressure. In the Spanish case, the multi-employer collective bargaining, that is compulsory for all sector firms, clearly benefits workers as it guarantees a minimum wage conditions to all workers of a sector, including those working at firms which could not sign their own collective agreement. At the same time, the system also benefits employers as having a labour regulation known and widely accepted by workers reduces those labour conflicts that could come up otherwise. This research shows that this regulation indeed impacts on wage setting: an increase of wage dispersion depending on firm size.

Data analysis clearly indicates that this effect is related to the collective bargaining, as MB mostly compresses wages. At the same time, it also regulates the labour relations of almost small firm workers. Firm collective bargaining promotion could cause greater wage dispersion, especially among workers at small firms, which are the bases of the Spanish business fabric. Following Canal and Rodriguez (2016), the structural reform of collective bargaining, proposed by the Socialist Party in 2011 and carried out by the People's Party (the main conservative party in Spain) in 2012, is aimed at decentralising collective bargaining, promoting firm-level bargaining by giving priority to firm-level bargaining. This change in the rules of the Spanish negotiating system was the first one since the creation of the collective bargaining system during the Spanish democratic transition in the late 1970s. 
It was imposed by the EU as one of the measures required to allow the Spanish banking system bailout. Besides, time analysis indicates the existence of a bottom-up wage compression in case of $\mathrm{MB}$. That is, this compression benefits workers with the lowest wages, bringing them closer to those with the highest wages (this is the most common negotiating level at small firms, which are a majority in Spain). Therefore, to promote firm-level bargaining means increasing dispersion by being detrimental to workers with the lowest wages. This does not only cause social problems (increasing household income gap), but it can also generate more potential labour conflicts, thus damaging the firm in the end.

This research could obviously be continued by assessing to what extent the 2012 labour reform could have changed the negotiating structure in Spain and so the wages.

\section{Notes}

1. See Brown and Medoff (1989), Idson and Oi (1999), Lallemand and Rycs (2007), Canal and Rodríguez (2016).

2. For the first time, 2010 and 2014 SSES included information on civil servants, who had been removed (they represented almost 8 per cent of surveyed workers) to guarantee data homogeneity in relation to 2006 survey. This fact increased the number of workers under firm bargaining by two points.

3. A limit of 50 workers to classify a firm as small was determined following the Recommendations of the Commission of the European Communities of 06/05/2003 (European Commission, 2003).

4. Worker characteristics: age, gender, education level, nationality, contract type, seniority, professional category. Firm characteristics: share capital, product market, sector, region.

5. Estimates are available upon request.

\section{References}

Arranz, J.M. and García-Serrano, C. (2014), "How green was my valley: earnings differentials and the changing distribution of wages in Spain", International Journal of Manpower, Vol. 35 No. 7, pp. 1059-1087.

Ashenfelter, R. and Layard, R. (1986), Handbook of Labor Economics, Elsevier, Amsterdam.

Barth, E. and Dale-Olsen, H. (2011), "Employer size or skill group size effect on wages?”, Industrial and Labour Relations Review, Vol. 2, pp. 341-355.

Blau, F. and Kahn, L. (1999), "Institutions and laws in the labor market", in Ashenfelter and Card. Handbook of Labor Economics, North-Holland, Amsterdam, Vol. 3, pp. 1399-1461.

Bover, O., Bentolila, S. and Arellano, M. (2002), "The distribution of earnings in Spain during the 1980s: the effects of skill, unemployment, and union power", in Cohen, D., Piketty, T. and Saint-Paul, G. (Eds), The Economics of Rising Inequalities, CEPR and Oxford University Press, Oxford, pp. 3-53.

Brown, C. and Medoff, J. (1989), "The employer size-wage effect”, Journal of Political Economy, Vol. 5, pp. 1027-1059.

Canal, J.F. and Rodríguez, C. (2004), "Collective bargaining and wage dispersion in Spain”, British Journal of Industrial Relations, Vol. 42 No. 3, pp. 481-506.

Canal, J.F. and Rodríguez, C. (2016), "Collective bargaining, wage dispersion and the economic cycle: Spanish evidence", The Economic and Labour Relations Review, Vol. 27 No. 4, pp. 471-489.

Card, D. and de la Rica, S. (2006), "Firm-level contracting and the structure of wages in Spain", Industrial and Labor Relations Review, Vol. 59 No. 4, pp. 573-592.

Calmfors, L. and Driffill, J. (1988), "Bargaining structure, corporatism and macroeconomic performance", Economic Policy, Vol. 3 No. 6, pp. 13-61.

Davis, S.J. and Haltiwanger, J. (1996), "Employer size and the wage structure in U.S. manufacturing", Annals of Economic and Statistics, Vols. 41-42, pp. 323-367. 
Dell'Aringa, C. and Lucifora, C. (1994), "Collective bargaining and relative earnings in Italy", European Journal of Political Economy, Vol. 10 No. 4, pp. 727-747.

Dell'Aringa, C. and Pagani, L. (2007), "Collective bargaining and wage dispersion”, British Journal of Industrial Relations, Vol. 45 No. 1, pp. 29-54.

DiNardo, J. and Lemieux, T. (1997), "Diverging male wage inequality in the United States and Canada, 1981-1988: do institutions explain the difference?", Industrial and Labor Relations Review, Vol. 50 No. 4, pp. 629-651.

Dolado, J.J., Felgueroso, F. and Jimeno, J.F. (1997), "The effects of minimum bargained wages on earnings: evidence from Spain”, European Economic Review, Vol. 41, pp. 713-721.

European Commission (2003), "Commission recommendation of 6 May 2003 concerning the definition of micro, small and medium-sized enterprises", notified under document number C(2003) (1422) (OJ L 124, 20.5.2003), European Commission, Brussels, pp. 36-41.

Gabaix, X. and Landier A. (2008), "Why has CEO pay increased so much?", The Quarterly Journal of Economics, Vol. 123 No. 1, pp. 49-100.

García-Serrano, C. and Malo, M.A. (2002), "Worker turnover, job turnover and collective bargaining in Spain”, British Journal of Industrial Relations, Vol. 401, pp. 69-85.

Gerlach, K. and Stephan, G. (2006), "Bargaining regimes and wage dispersion", Jahrbücher für Nationalökonomie und Statistik, Vol. 226 No. 6, pp. 629-645.

Idson, T.L. and Oi, W.J. (1999), "Workers are more productive in large firms", American Economic Review, Vol. 89 No. 2, pp. 104-108.

Kim, I. and Konings, J. (2018), "Wage inequality and firm heterogeneity”, C.E.P.R. Discussion Paper No. 12698.

Lallemand, T. and Rycx, F. (2005), "Firm size and the dispersion of wages: evidence from European countries", Discussion Paper No. 1778, Institute for the Study of Labor, Bonn.

Lallemand, T. and Rycx, F. (2007), "Employer size and the structure of wages: a critical survey", Reflets et Perspectives, Vol. 61, Nos 2007/2-3, pp. 75-87.

Lorences, J., Fernández, V. and Rodríguez, C. (1994), "Diferencias interterritoriales de salarios y negociación colectiva en España”, Investigaciones Económicas, Vol. 19, pp. 309-324.

Mueller, H., Ouimet, P. and Simintzi, E. (2017a), "Wage inequality and firm growth", American Economic Review: Papers and Proceedings, Vol. 107 No. 5, pp. 379-383.

Mueller, H., Ouimet, P. and Simintzi, E. (2017b), "Within-firm pay inequality”, The Review of Financial Studies, Vol. 30 No. 10, pp. 3605-3635.

OECD (2004), Employment Outlook, Organisation for Economic Cooperation and Development, Paris.

OECD (2014), Employment Outlook, Organisation for Economic Cooperation and Development, Paris.

Palacio, J.I. and Simón, H. (2002), "Dispersión salarial y negociación colectiva en España”, Cuadernos Relaciones Laborales, Vol. 201, pp. 169-187.

Palacio, J.I. and Simón, H. (2004), "Dispersión salarial entre establecimientos y desigualdad salarial en España”, Revista de Economía Aplicada, Vol. 1236, pp. 47-81.

Pehkonen, J., Pehkonen, S. and Strifler, M. (2017), "Wage effects of firm-size: evidence from linked employer-employee panel”, Finnish Economic Papers, Vol. 28 No. 1, pp. 1-9.

Plasman, R., Rusinek, M. and Rycx, F. (2006), "Wages and the bargaining regime under multi-level bargaining: Belgium, Denmark and Spain”, Discussion Paper No. 1990, Institute for the Study of Labor, Bonn.

Rodríguez, C. (2001), "Wage dispersion within firms and collective bargaining in Spain", Economics Letters, Vol. 72, pp. 381-386.

Rodríguez, C. and Canal, J.F. (2016), "Análisis de las inaplicaciones de convenios tras la reforma laboral”, Revista de Economía Laboral, Vol. 13 No. 2, pp. 65-91. 
Spanish Economic and Social Council (2014), Report on the Socioeconomic and Labour Situation, Spanish Economic and Social Council, Madrid.

Sulis, G. (2014), "Wage returns to experience and tenure for young men in Italy", Scottish Journal of Political Economy, Vol. 61 No. 5, pp. 559-588.

Teulings, C. and Hartog, J. (1998), Corporatism or Competition? Labour Contracts, Institutions and Wage Structures in International Comparison, Cambridge University Press, Cambridge.

Terviö, M. (2008), “The difference that CEOs make: an assignment model approach”, The American Economic Review, Vol. 98 No. 3, pp. 642-668.

Wallerstein, M. (1999), "Wage-setting institutions and pay inequality in advanced industrial societies", American Journal of Political Science, Vol. 43 No. 3, pp. 649-680.

\section{Corresponding author}

Juan Francisco Canal Domínguez can be contacted at: jfcanal@uniovi.es

For instructions on how to order reprints of this article, please visit our website: 